\title{
Life table parameters of the aphid predators Coccinella septempunctata, Ceratomegilla undecimnotata and Propylea quatuordecimpunctata (Coleoptera: Coccinellidae)
}

\author{
Dimitrios C. KONTODimaS ${ }^{1}$, Panagiotis G. MilONAS ${ }^{1}$, George J. StATHAS ${ }^{2}$, Nickolaos E. PAPANIKOLAOU ${ }^{3}$, \\ ANNA SKOURTI ${ }^{1,2}$ and YIANNIS G. MATSINOS ${ }^{3}$
}

${ }^{1}$ Benaki Phytopathological Institute, 8 Stefanou Delta, 14561 Kifissia, Greece; e-mail: d.kontodimas@bpi.gr

${ }^{2}$ Technological Educational Institute of Kalamata, 24100 Antikalamos, Greece

${ }^{3}$ Aegean University, Mytilene, Greece

Key words. Coccinellidae, Coccinella septempunctata, Ceratomegilla undecimnotata, Propylea quatuordecimpunctata, Aphis fabae, fecundity, life tables

\begin{abstract}
The life tables of the aphid predators Coccinella septempunctata L., Ceratomegilla undecimnotata (Schneider) and Propylea quatuordecimpunctata (L.) (Coleoptera: Coccinellidae), fed on Aphis fabae Scopoli (Hemiptera: Aphididae), were constructed at constant conditions $\left(25 \pm 1{ }^{\circ} \mathrm{C}, 65 \pm 2 \% \mathrm{RH} ; 16 \mathrm{~L}: 8 \mathrm{D}\right)$. The average total fecundities of $C$. septempunctata, C. undecimnotata and P. quatuordecimpunctata were 1996.8, 1160.5, and 724.6 eggs / female, and the average longevities were 94.9, 88.3, and 68.9 days, respectively. The net reproductive rates $\left(R_{0}\right)$ were 1004.1, 544.3, and 375.1 females/female, and the intrinsic rates of increase $\left(r_{m}\right)$ $0.118,0.142$ and 0.166 females/female/day, respectively.
\end{abstract}

\section{INTRODUCTION}

Coccinellid aphid predators have been studied worldwide for integration with biological control systems. Frequently, ladybirds have been introduced accidentally or deliberately into new environments where their invasive behavior was a topic of considerable controversy. The use of non-native predatory species to suppress aphid populations has led to some extent to unexpected harm for local ecosystem (Galvan et al., 2006). The study and use of native indigenous species in biocontrol projects is encouraged prior to the search for, and import of, non-native species.

Life table parameters are a precision tool used by researchers for the selection of the most suitable biocontrol agent (Messenger, 1964). The intrinsic rate of increase, $r_{m}$, is of great importance among other parameters for selecting candidate species as biocontrol agents. The intrinsic rate of population increase of the predator should be equal to, or greater than, that of its prey.

In the present study the life table parameters of Coccinella septempunctata, Ceratomegilla undecimnotata and Propylea quatuordecimpunctata (Coleoptera: Coccinellidae) feeding on Aphis fabae Scopoli (Hemiptera: Aphididae), an essential food for all predator species examined, were constructed based on observed life-time fecundities. The following life table parameters were calculated: age specific survival and fecundity, reproductive value, expected remaining life time, net reproductive value, intrinsic rate of increase, mean generation time, finite rate of increase and doubling time. The above parameters can be used to estimate the rate of increase of a natural or released population (El Hag \& Zaitoon, 1996) and to determine when to release laboratory-reared coccinellid. In addition, the survival of adult females were described using the Weibull distribution.

\section{MATERIAL AND METHODS}

The predators were originally collected in summer 2006 from the field (C. septempunctata and C. undecimnotata from Copais plain preying on Myzus persicae infesting Nicotiana tabacum and Propylea quatuordecimpunctata from Arta plain preying on Rhopalosiphum maydis infesting Zea mays). All predators were reared for two generations in large cylindrical Plexiglas cages (50 cm length $\times 30 \mathrm{~cm}$ diameter) containing an abundance of prey of mixed instars (Aphis fabae reared on Vicia faba) under the following controlled conditions: $25 \pm 1{ }^{\circ} \mathrm{C} ; 65 \pm 2 \% \mathrm{RH}$; $16 \mathrm{~L}$ : 8D. The prey used, A. fabae is listed as an essential food for the three predators used in the current study (Hodek \& Honěk, 1996).

The fecundity of the three predators was determined using 25 newly emerged pairs of adults of each species, which were kept (each pair separately) in plastic cylindrical cages $(10 \mathrm{~cm}$ diameter $\times 5 \mathrm{~cm}$ height) under the above mentioned constant conditions. Each day aphids were added in the cages. Replacement of the males was not required because no early mortality or infertility was observed. In the same laboratory conditions we observed the development and survival of the immature stages (30 individuals) and the sex ratio of the progeny (by counting 200 offspring). These experiments were done in the autumn of 2006. Each day, eggs that were produced in the cages were counted and removed. Observations ended after death of females. For each species life table parameters were calculated (Tables 1 and 2). Life table parameters of other coccinellid species have been studied in similar conditions in east Mediterranean (Uygun \& Atlihan, 2000; Kontodimas \& Stathas, 2005; Kontodimas et al., 2007).

In addition, the Weibull frequency distribution was used to describe the age specific survival of female adults. The prob- 
TABLE 1. Summary of the life tables for the experimental populations of Coccinella septempunctata L., Ceratomegilla undecimnotata (Schneider) and Propylea quatuordecimpunctata (L.) (Coleoptera: Coccinellidae), fed on Aphis fabae Scopoli (Hemiptera: Aphididae), under constant conditions $\left(25 \pm 1^{\circ} \mathrm{C}, 65 \pm 2 \% \mathrm{RH} ; 16 \mathrm{~L}: 8 \mathrm{D}\right)$.

\begin{tabular}{|c|c|c|c|c|c|c|}
\hline & & $\begin{array}{c}\text { Observation } \\
\text { day }\end{array}$ & $\begin{array}{l}\text { Age specific } \\
\text { survival }\left(l_{x}\right)\end{array}$ & $\begin{array}{c}\text { Age specific fecundity }\left(m_{x}\right)^{*} \\
(15 \text {-days sum }) \\
\text { (females/female) }\end{array}$ & $\begin{array}{l}\text { Reproductive value }\left(V_{x}\right) \\
V_{x}=\frac{\sum_{y=x}\left(e^{r m \cdot} \cdot l_{y} \cdot m_{y}\right)}{l_{x} \cdot e^{r m \cdot x}} \\
(\text { females/female })\end{array}$ & $\begin{array}{l}\text { Expected remaining } \\
\text { life time }\left(E_{x}\right)(\text { days }) \\
\qquad E_{x}=\frac{\sum_{y=x} \frac{l_{y+1}}{2}}{l_{x}}\end{array}$ \\
\hline \multirow{12}{*}{$\begin{array}{l}\text { C. septem- } \\
\text { punctata }\end{array}$} & \multirow{2}{*}{ Immature } & 1 & 1 & 0.0 & 1.1 & 106.4 \\
\hline & & 15 & 0.96 & 0.0 & 6.1 & 101.0 \\
\hline & \multirow{10}{*}{ Adult } & $28 * *$ & 0.93 & 0.0 & 29.4 & 93.8 \\
\hline & & 45 & 0.93 & 55.9 & 151.3 & 77.9 \\
\hline & & 60 & 0.93 & 265.2 & 138.3 & 62.9 \\
\hline & & 75 & 0.93 & 230.1 & 128.9 & 47.9 \\
\hline & & 90 & 0.93 & 224.6 & 97.6 & 32.9 \\
\hline & & 105 & 0.63 & 170.2 & 72.7 & 28.1 \\
\hline & & 120 & 0.37 & 155.0 & 66.1 & 26.6 \\
\hline & & 135 & 0.30 & 105.5 & 34.8 & 15.1 \\
\hline & & 150 & 0.11 & 85.9 & 32.3 & 13.5 \\
\hline & & 165 & 0.07 & 70.2 & 0.0 & 1.0 \\
\hline \multirow{11}{*}{$\begin{array}{l}\text { C. undecim- } \\
\text { notata }\end{array}$} & \multirow{2}{*}{ Immature } & 1 & 1 & 0 & 1.2 & 99.8 \\
\hline & & 15 & 0.93 & 0 & 9.1 & 94.2 \\
\hline & \multirow{9}{*}{ Adult } & $25 * *$ & 0.89 & 0 & 39.2 & 87.9 \\
\hline & & 30 & 0.89 & 3.4 & 79.9 & 82.9 \\
\hline & & 45 & 0.89 & 180.9 & 73.3 & 67.9 \\
\hline & & 60 & 0.89 & 148.6 & 70.7 & 52.9 \\
\hline & & 75 & 0.89 & 136.4 & 49.8 & 37.9 \\
\hline & & 90 & 0.89 & 94.0 & 19.9 & 22.9 \\
\hline & & 105 & 0.57 & 38.5 & 7.8 & 14.3 \\
\hline & & 120 & 0.18 & 19.5 & 9.8 & 12.3 \\
\hline & & 135 & 0.07 & 24.7 & 0.0 & 1.5 \\
\hline \multirow{10}{*}{$\begin{array}{l}\text { P. quatuorde- } \\
\text { cimpunctata }\end{array}$} & \multirow{2}{*}{ Immature } & 1 & 1 & 0 & 1.0 & 82.4 \\
\hline & & 15 & 0.96 & 0 & 12.5 & 70.6 \\
\hline & \multirow{8}{*}{ Adult } & $18^{* *}$ & 0.96 & 0 & 20.6 & 67.6 \\
\hline & & 30 & 0.96 & 56.1 & 49.8 & 55.6 \\
\hline & & 45 & 0.96 & 117.9 & 49.4 & 40.6 \\
\hline & & 60 & 0.92 & 111.1 & 40.0 & 26.8 \\
\hline & & 75 & 0.69 & 90.7 & 20.2 & 17.9 \\
\hline & & 90 & 0.38 & 37.7 & 4.0 & 12.2 \\
\hline & & 105 & 0.15 & 21.9 & 6.0 & 7.0 \\
\hline & & 118 & 0.04 & 14.2 & 0.0 & 1.0 \\
\hline
\end{tabular}

* by multiplying the mean number of eggs by the ratio $\$ /(q+\delta)($ Liu et al., 1997); ** adults' emergence.

ability that an individual lives at least to time $t$ was calculated by the equation: $S_{(t)}=e^{-\left(\frac{t}{b}\right)^{c}}$, for $t>0$, where $b$ is a scale parameter that is inversely related to the mortality rate and $c$ is a shape parameter that allows the model to produce survival distributions of different forms (Deevey, 1947; Pinder et al., 1978). Values of the shape parameter $c>1,=1$ or $<1$ correspond to Deevey's type I, II or III survivorship curves, respectively. Estimates of the models' parameters and coefficients of non-linear regression $\left(\mathrm{R}^{2}\right)$ were obtained with statistical packages JMP v.4.0.2 (SAS, 1989) and SPSS v.9.0.0 (SPSS, 1999).

\section{RESULTS AND DISCUSSION}

The average total fecundities of $C$. septempunctata, $C$. undecimnotata and $P$. quatuordecimpunctata were 1996.8, 1160.5, and 724.6 eggs / female, and the average longevities 94.9, 88.3, and 68.9 days, respectively. These fecundities data are much higher than those reported for $C$. septempunctata and $P$. quatuordecimpunctata in previous studies (Xia et al., 1999; Phoofolo \& Obrycki, 2000). It is notable that Xia et al. (1999) reported an unusually low fecundity for $C$. septempunctata of only 287 eggs at $25^{\circ} \mathrm{C}$. In general a long lived coccinellid is 
TABLE 2. Life table parameters for Coccinella septempunctata L., Ceratomegilla undecimnotata (Schneider) and Propylea quatuordecimpunctata (L.) (Coleoptera: Coccinellidae), fed on Aphis fabae Scopoli (Hemiptera: Aphididae), under constant conditions $\left(25 \pm 1^{\circ} \mathrm{C}, 65 \pm 2 \% \mathrm{RH} ; 16 \mathrm{~L}: 8 \mathrm{D}\right)$.

\begin{tabular}{|c|c|c|c|}
\hline Life table parameter & C. septempunctata & C. undecimnotata & P. quatuordecimpunctata \\
\hline $\begin{array}{l}\text { Net reproductive value } \\
\quad R_{0}=\Sigma\left(l_{x} \cdot m_{x}\right) \\
\text { (females/female) }\end{array}$ & 1004.1 & 544.3 & 375.1 \\
\hline $\begin{array}{l}\text { Intrinsic rate of increase }\left(r_{m}\right) * \\
\quad(\text { females/female/day) }\end{array}$ & 0.118 & 0.142 & 0.166 \\
\hline $\begin{array}{c}\text { Mean generation time } \\
T=\frac{\ln R_{0}}{r_{m}} \text { (days) }\end{array}$ & 58.6 & 44.3 & 35.7 \\
\hline $\begin{array}{c}\text { Doubling time } \\
D T=\frac{\ln }{r_{m}} \text { (days) }\end{array}$ & 5.9 & 4.8 & 4.2 \\
\hline Finite rate of increase $\lambda=e^{r_{m}}$ & 1.13 & 1.15 & 1.18 \\
\hline Weibull b parameter & 104.1918 & 93.6051 & 74.3178 \\
\hline Weibull c parameter & 4.6978 & 7.7546 & 4.7660 \\
\hline $\mathrm{R}^{2}$ of Weibull equation & 0.9697 & 0.9780 & 0.9878 \\
\hline RSS of Weibull equation & 0.5518 & 0.2925 & 0.1753 \\
\hline
\end{tabular}

* from the solution of the Euler equation: $\sum\left(e^{r_{m} x} \cdot l_{x} \cdot m_{x}\right)=1$

expected to be associated with high fecundity and larger species are likely to be more fecund than smaller species (Dixon, 2000). However, the most fecund species is not always the most successful in reducing prey abundance since there seems to be a trade-off between fecundity and longevity.

The summaries of the life tables of the three predators are presented in Table 1. It is noticeable that all three coccinellids show higher reproductive values $\left(\mathrm{V}_{\mathrm{x}}\right)$ between 30-60 days after egg hatching with a satisfactorily high expected remaining life time $\left(\mathrm{E}_{\mathrm{x}}\right)$. The largest and more long-lived coccinellid $C$. septempunctata shows the highest reproductive value ( 151.3 females/female) at the $45^{\text {th }}$ day after egg hatching ( $=17$ days after adult emergence), whereas $C$. undecimnotata has the highest reproductive value ( 79.9 females/female) at the $30^{\text {th }}$ day after egg hatching (= 5 days after adult emergence) and $P$. quatuordecimpunctata has 49.8 females/female also at the $30^{\text {th }}$ day after egg hatching (= 12 days after adult emergence). The respective value for Hippodamia (Adonia) variegata, reared in the same conditions on Dysaphis crataegi (Kontodimas \& Stathas, 2005), is $\mathrm{V}_{\mathrm{x}}=151.3$ females/female at the $30^{\text {th }}$ day after egg hatching $(=17$ days after adults' emergence).

The life table parameters $R_{0}, r_{m}, T, D T$ and $\lambda$ are presented in Table 2. It is noticeable that as far as the net reproductive value $\left(R_{0}\right)$ is concerned C. septempunctata $>$ C. undecimnotata $>$ P. quatuordecimpunctata, but for the intrinsic rate of increase $\left(r_{m}\right.$ or $\left.r_{c}\right)$ the order is the opposite. The respective values of $R_{0}$ and $r_{m}$ for $H$. variegata are $R_{0}=425.9$ females/female and $r_{m}=0.178$ females/female/day) (Kontodimas \& Stathas, 2005), that is the highest $r_{m}$ and the third $R_{0}$, comparing with the results of the current study. Finally as far as the Weibull shape parameter $c$ is concerned, for all species it corresponds to type I survival curve, as $c>1$ (Table 2). An effective predator should have an intrinsic rate at least equal to that of its prey to be able to reduce its abundance. In our study although $P$. quatuordecimpunctata has the lowest fecundity on the other hand it is the species with a high intrinsic rate of population increase.

The values of the parameters obtained of the current study are useful for comparison between coccinellid species and may be used for understanding their population dynamics.

\section{REFERENCES}

DeEvey E.S. 1947: Life tables for natural populations of animals. Quart. Rev. Biol. 22: 283-314.

Dixon A.F.G. 2000: Insect Predator-Prey Dynamics: Ladybird Beetles and Biological Control. Cambridge University Press, Cambridge, $257 \mathrm{pp}$.

El Hag E.A. \& Zaitoon A.A. 1996: Biological parameters for four coccinellid species in central Saudi Arabia. Biol. Contr. 7: 316-319.

Galvan T.L., Burkness E.C. \& Hutchison W.D. 2006: Wine Grapes in the Midwest: Reducing the Risk of the Multicolored Asian Lady Beetle. Public. 08232. Univ. of Minnesota Extension Service, St. Paul, MN.

HodeK I. \& HonĚK A. 1996: Ecology of Coccinellidae. Kluwer Academic Publishers, Dordrecht, $464 \mathrm{pp}$.

Kontodimas D.C. \& Stathas G.J. 2005: Phenology, fecundity and life table parameters of the predator Hippodamia variegata reared on Dysaphis crataegi. BioControl 50: 223-233.

Kontodimas D.C., Milonas P.G., Stathas G.J., Economou L.P. \& Kavallieratos N.G. 2007: Life table parameters of the pseudococcids' predators Nephus includens and Nephus bisignatus (Coleoptera: Coccinellidae). Eur. J. Entomol. 104: 407-415.

Liu T.X., Stansly P.A., Hoelmer K.A. \& Osborne L.S. 1997: Life history of Nephaspis oculatus (Coleoptera: Coccinellidae) a predator of Bemisia tabaci (Homoptera: Aleyrodidae). Ann. Entomol. Soc. Am. 90: 776-782.

Messenger P.S. 1964: Use of life tables in a bioclimatic study of an experimental aphid-braconid wasp host-parasite system. Ecology 45: 119-131. 
Phoofolo M.P. \& ObRYcki J.J. 2000: Demographic analysis of reproduction in nearctic and palearctic populations of Coccinella septempunctata and Propylea quatuordecimpunctata. BioControl 45: 25-43.

Pinder J.E., Wiener J.G. \& SMith M.H. 1978: The Weibull distribution: a new method of summarizing survivorship data. Ecology 59: 175-179.

SAS Institute 1989: JMP, A Guide to Statistical and Data Analysis, v. 4.0.2. SAS Institute Inc., Cary, NC.

SPSS 1999: SPSS 9 for Windows, User's Guide. SPSS Inc. Chicago, IL.
Uygun N. \& Atlihan R. 2000: The effect of temperature on development and fecundity of Scymnus levaillanti. BioControl 45: 453-462.

XIA J.Y., VAN DER WERF W. \& RABbinge R. 1999: Temperature and prey density effects on bionomics of Coccinella septempunctata (Coleoptera: Coccinellidae) feeding on Aphis gossypii (Homoptera: Aphididae) on cotton. Environ. Entomol. 28: 307-314.

Received September 24, 2007; revised and accepted November 29, 2007 